\section{Intestinal paracellular permeability during malnutrition in guinea pigs: effect of high dietary zinc}

\author{
P Rodríguez, N Darmon, P Chappuis, C Candalh, M A Blaton, C Bouchaud, $M$ Heyman
}

$\begin{array}{ll}\text { Laboratoire de } & \begin{array}{l}\text { with increased intestinal paracellular } \\ \text { permeability to small molecules, and }\end{array} \\ \text { Cytologie, } & \begin{array}{l}\text { pharmacological doses of zinc prevent } \\ \text { Université Paris VI, }\end{array} \\ \text { Institut de } & \text { (Gut 1996; 39: 416-422) } \\ \text { Neurosciences, } & \end{array}$

Paris, France

P Rodríguez

C Bouchaud

INSERM U 290,

Hôpital St Lazare,

Paris, France

N Darmon

C Candalh

M A Blaton

M Heyman

Laboratoire Central de Biochimie, Hôpital Lariboisière, Paris, France P Chappuis

Correspondence to: Dr M Heyman, INSERM U 290 ,

Hôpital St Lazare, 107 rue du Fg St Denis, 75010 Paris, France.

Accepted for publication 4 April 1996

Keywords: malnutrition, zinc, tight junction, paracellular permeability, intestine, guinea pig.

Malnutrition, similar to intestinal diseases such as inflammatory bowel disease, gastrointestinal allergy, coeliac disease, and toxigenic diarrhoea, is associated with intestinal dysfunction. In children with diarrhoea, oral zinc supplementation was shown to improve intestinal permeability $^{1}$ and to reduce the severity and duration of diarrhoea. ${ }^{2}$ The effects of zinc were more pronounced in the subgroup of malnourished children, suggesting that the intestinal dysfunction linked to malnutrition responds positively to zinc treatment.

In both human and animal malnutrition, intestinal transport of macromolecules in-

\begin{abstract}
Background-Zinc has been shown to have beneficial effects in vitro on epithelial barrier function, and in vivo to reduce intestinal permeability in malnourished children with diarrhoea. Aims-To determine whether malnutrition alters intestinal paracellular permeability, and whether zinc prevents such alterations.

Methods-Guinea pigs were fed a normal protein diet (NP group), a low protein diet (LP group), or a low protein diet enriched with 1800 ppm zinc (LPZn group) for three weeks. Intestinal permeability was measured on jejunal segments mounted in Ussing chambers by measuring ionic conductance and mucosal to serosal fluxes of ${ }^{14} \mathrm{C}$-mannitol, ${ }^{22} \mathrm{Na}$, and horseradish peroxidase. Tight junction morphology was assessed on cryofracture replicas.

Results-Mannitol and $\mathrm{Na}$ fluxes and ionic conductance increased in the LP group compared with the NP group but remained normal in the LPZn group. Accordingly, jejunal epithelia from the LP group, but not from the LPZn group, showed a small decrease in number of tight junctional strands compared with epithelia from the NP group. Neither malnutrition nor zinc treatment modified horseradish peroxidase fluxes.

Conclusions-Malnutrition is associated with increased intestinal paracellular permeability to small molecules, and (Gut 1996; 39: 416-422)
\end{abstract}

creases, ${ }^{3-6}$ and intestinal ionic conductance and small solute permeability are also enhanced ${ }^{7} 8$ indicating that function of the intestinal barrier is altered during malnutrition. These findings raise the question of morphological integrity of the intestinal epithelium during malnutrition, as intestinal morphology is strongly implicated in the barrier function. ${ }^{9}$ In the intestinal epithelium the paracellular permeability is mainly governed by tight junctions. They provide a continuous seal around the apical region of adjacent cells, restricting the free passage of molecules and ions across the paracellular pathway. They are regulated at the cellular level by the cytoskeleton ${ }^{10}$ and are physiologically modulated by nutrients. ${ }^{11}$ Cytokines such as interferon $\gamma(\text { IFN } \gamma)^{12}$ or tumour necrosis factor $\alpha(\mathrm{TNF} \alpha),{ }^{13}$ and pathological events such as the transmigration of polymorphonuclear cells, ${ }^{14}$ have been shown to alter the intestinal epithelial barrier in vitro, as indicated by the increase in the paracellular permeability of filter grown intestinal cells, and by morphological changes in the tight junction network. Interestingly, in a model of endothelial monolayers, zinc was mandatory to normal barrier function ${ }^{15}$ and prevented the disruption of this barrier by TNF $\alpha{ }^{16}$

The first objective of this study was to gain insight into the mechanisms by which the intestinal barrier is altered during malnutrition. We therefore analysed the morphological and functional alterations that occurred in the jejunal epithelium of malnourished guinea pigs. The second objective was to assess the ability of pharmacological doses of zinc to prevent intestinal barrier dysfunction in our malnourished guinea pigs.

\section{Methods}

ANIMALS AND DIETS

Thirty weanling Dunkin-Hartley guinea pigs (Charles River, Saint-Aubin les Elbeuf, France) weighing 178 (SD 8) g at day 0, were used.

They were maintained at room temperature under a 12 hour light: 12 hour dark cycle, fed ad libitum with three different diets for three weeks, and given free access to water. The diets were based on the known nutritional requirements of these animals ${ }^{17}$ and were purchased from INRA/APAE, Jouy en Josas, France. Table I shows details of their composition. As guinea pigs are prone to 
TABLE I Composition of the diets

\begin{tabular}{lrcc}
\hline Ingredients (g/100g diet) & $N P$ & $L P$ & $L P Z n$ \\
\hline Soya proteins & $30 \cdot 0$ & $4 \cdot 0$ & $4 \cdot 0$ \\
L-Methionine & $0 \cdot 3$ & $0 \cdot 04$ & $0 \cdot 04$ \\
Saccharose & $14 \cdot 4$ & $23 \cdot 15$ & $22 \cdot 88$ \\
Corn starch & $28 \cdot 8$ & $46 \cdot 31$ & $45 \cdot 78$ \\
Corn oil & $5 \cdot 0$ & $5 \cdot 0$ & $5 \cdot 0$ \\
Cellulose & $14 \cdot 0$ & $14 \cdot 0$ & $14 \cdot 0$ \\
Vitamin mixture & $1 \cdot 0$ & $1 \cdot 0$ & $1 \cdot 0$ \\
Mineral mixture & $6 \cdot 5$ & $6 \cdot 5$ & $6 \cdot 5$ \\
Additional zinc $\left(\mathrm{ZnSO}_{4} 7 \mathrm{H}_{2} \mathrm{O}\right)$ & - & - & $0 \cdot 8$ \\
\hline
\end{tabular}

$\mathrm{NP}=$ normal protein diet; $\mathrm{LP}=$ low protein diet; $\mathrm{LPZn}=$ low protein diet with $1800 \mathrm{ppm}$ zinc.

*Vitamin mixture (IU or mg/kg diet): retinyl palmitate, 25000 IU/kg; cholecalciferol, $2000 \mathrm{IU} / \mathrm{kg}$; dl-tocopheryl acetate, 135

IU/kg; menadione, $20 \mathrm{mg} / \mathrm{kg}$; thiamin $\mathrm{HCl}, 20 \mathrm{mg} / \mathrm{kg}$;

riboflavin, $20 \mathrm{mg} / \mathrm{kg}$; nicotinic acid, $200 \mathrm{mg} / \mathrm{kg}$; calcium

D-pantothenate, $40 \mathrm{mg} / \mathrm{kg}$; pyridoxine $\mathrm{HCl}, 15 \mathrm{mg} / \mathrm{kg}$;
inositol, $2000 \mathrm{mg} / \mathrm{kg}$; D-biotin, $0.8 \mathrm{mg} / \mathrm{kg}$; folic acid, $10 \mathrm{mg} /$

inositol, $2000 \mathrm{mg} / \mathrm{kg}$; D-biotin, $0.8 \mathrm{mg} / \mathrm{kg}$; folic acid, 10

pa; cyanocobalamin, $0.04 \mathrm{mg} / \mathrm{kg}$; ascorbic acid, $2 \mathrm{~g} / \mathrm{kg}$;

paraaminobenzoic acid, $10 \mathrm{mg} / \mathrm{kg}$; saccharose, $2.5 \mathrm{~g} / \mathrm{kg}$.
† Mineral mixture (g or mg/kg diet): $\mathrm{CaHPO}_{4}-2 \mathrm{H}_{2} \mathrm{O}, 8.33 \mathrm{~g} / \mathrm{kg}$;

$\mathrm{CaCO}_{3}, 14.56 \mathrm{~g} / \mathrm{kg} ; \mathrm{NaCl}, 2 \cdot 81 \mathrm{~g} / \mathrm{kg} ; \mathrm{KCl}, 4.52 \mathrm{~g} / \mathrm{kg}$;

$\mathrm{CH}_{3} \mathrm{COOK}, 27 \cdot 10 \mathrm{~g} / \mathrm{kg} ; \mathrm{FeSO}_{4} 7 \mathrm{H}_{2} \mathrm{O}, 0.40 \mathrm{~g} / \mathrm{kg} ; \mathrm{MnSO}_{4}$

$\mathrm{H}_{2} \mathrm{O}, 0.40 \mathrm{~g} / \mathrm{kg} ; \mathrm{MgSO}_{4} 7 \mathrm{H}_{2} \mathrm{O}, 1.50 \mathrm{~g} / \mathrm{kg} ; \mathrm{MgO}, 5.00 \mathrm{~g} / \mathrm{kg}$;

$\mathrm{CuSO}_{4}-5 \mathrm{H}_{2} \mathrm{O}, 0.04 \mathrm{~g} / \mathrm{kg} ; \mathrm{NaF}, 0.04 \mathrm{~g} / \mathrm{kg} ; \mathrm{KI}, 0.03 \mathrm{~g} / \mathrm{kg}$;

$\left(\mathrm{NH}_{4}\right)_{6} \mathrm{MO}_{7} \mathrm{O}_{24} 4 \mathrm{H}_{2} \mathrm{O}, 0.90 \mathrm{mg} / \mathrm{kg} ; \mathrm{CoSO}_{4} 7 \mathrm{H}_{2} \mathrm{O}, 0.03 \mathrm{~g} / \mathrm{kg}$

$\mathrm{Na}_{2} \mathrm{SeO}_{3}, 0.90 \mathrm{mg} / \mathrm{kg} ; \mathrm{ZnSO}_{4} 7 \mathrm{H}_{2} \mathrm{O}, 0 \cdot 20 \mathrm{~g} / \mathrm{kg}(45 \mathrm{ppm} \mathrm{Zn})$.

develop sensitisation to milk proteins, soya proteins were used as the source of dietary proteins. The guinea pigs were divided into three dietary groups, fed a normal protein diet (NP, 30\% soya protein, $n=12$ ), a low protein diet (LP, $4 \%$ soya protein, $n=12$ ), and a low protein diet enriched with $0.8 \%(1800 \mathrm{ppm})$ $\mathrm{ZnSO}_{4} 7 \mathrm{H}_{2} \mathrm{O}$ (LPZn, $\left.\mathrm{n}=6\right)$. The LP and NP diets contained adequate zinc (45 ppm). As zinc has been reported to be non-toxic even at doses of more than 100 times the recommended dietary allowance, ${ }^{18}$ especially in the guinea pig, ${ }^{17}$ we chose a dose of 1800 ppm zinc on the assumption that its effects would be apparent in the LPZn group. This large amount of zinc constitutes a pharmacological dose that may not apply to supplementation in human malnutrition. Isocaloric dietary adjustments were made with saccharose and corn starch $(1 / 3: 2 / 3 \mathrm{w} / \mathrm{w})$. As soya proteins are deficient in amino acids containing sulphur, diets were supplemented with methionine ( $1 \%$ of the soya content). Because low protein diets are known to induce anorexia, ${ }^{19}$ animals given such diets probably have protein energy malnutrition rather than strict protein deficiency.

EXPERIMENTAL DESIGN

After 18-20 days on their respective diets, guinea pigs were fasted for 18 hours, anaesthetised intraperitoneally with a lethal dose of sodium pentobarbitone $(90 \mathrm{mg} / \mathrm{kg}$ ). The jejunum was removed and carefully rinsed free of intestinal content with cold Ringer's solution containing (in $\mathrm{mM}$ ) $140 \mathrm{Na}^{+}, 5 \cdot 2 \mathrm{~K}^{+}$, $120 \mathrm{Cl}^{-}, 25 \mathrm{HCO}_{3}^{-}, 1 \cdot 2 \mathrm{Ca}^{2+}, 2 \cdot 4 \mathrm{HPO}_{4}{ }^{2-}, 0 \cdot 4$ $\mathrm{H}_{2} \mathrm{PO}_{4}^{-}, 1 \cdot 2 \mathrm{Mg}^{2+}$, and 2 glutamine. The jejunum was then stripped of the outer muscle layer and fixed for electron microscopy. Other pieces of jejunum were opened along the mesenteric border and immediately mounted in Ussing chambers for permeability studies. Plasma samples and some jejunal segments were also collected and stored at $-80^{\circ} \mathrm{C}$ for zinc and protein assays by flame atomic absorption and Folin reagent respectively. All these experiments were done according to the principles of laboratory animal care.

ANALYSIS OF ZINC STATUS OF GUINEA PIGS

The zinc concentration was measured in the plasma and intestine of guinea pigs from the three dietary groups. Plasma was diluted 1:5 with doubly deionised water and intestinal homogenates were mineralised in Teflon bombs placed in a microwave enclosure (MDS81D, CEM Corp, Matthews, USA) as follows: $50 \mu \mathrm{l}$ intestinal homogenates were mineralised with $300 \mu \mathrm{l}$ ultrapure nitric acid at $500 \mathrm{~W}$ for five minutes and then appropriately diluted with doubly deionised water. Samples were analysed for zinc by air-acetylene flame atomic absorption (Perkin-Elmer spectrophotometer model 2380, Norwalk, CT, USA) at a wavelength of $213.8 \mathrm{~nm}$.

INTESTINAL PERMEABILITY STUDY

Intestinal permeability was analysed in 24 animals only. Four adjacent jejunal segments from each animal were mounted in Ussing chambers as flat sheets with an exposed area of $0.1 \mathrm{~cm}^{2}$. They were bathed on both sides with $1.5 \mathrm{ml}$ Ringer's solution, which was continuously circulated at constant temperature, oxygenated, and maintained at pH $7 \cdot 4$ with $5 \% \mathrm{CO}_{2}$ in $95 \% \mathrm{O}_{2}$. The mucosal and serosal bathing solutions were connected via agar bridges to calomel electrodes for measurement of the transepithelial potential difference and to $\mathrm{Ag}-\mathrm{AgCl}$ electrodes for current application. The tissue was kept under short circuit conditions by an automatic clamping device (World Precision Instruments Inc, New Haven, CT, USA) that cancelled out fluid resistance. Short circuit current was constantly recorded and the tissue was pulsed at $5 \mathrm{mV}$ every 30 seconds. The short circuit current deflection was used to calculate ionic conductance (or its reverse, electrical resistance) according to Ohm's law. Steady state potential difference, short circuit current, and ionic conductance 30 minutes after tissue mounting were taken as baseline electrical variables. After equilibration, $5 \mathrm{mM}$ mannitol was added to both the mucosal and serosal compartments, and $20 \mathrm{kBq} / \mathrm{ml}{ }^{14} \mathrm{C}$-mannitol, $20 \mathrm{kBq} / \mathrm{ml}^{22} \mathrm{Na}^{+}$(both from NEN, Dupont de Nemours, France), and $0.4 \mathrm{mg} / \mathrm{ml}$ of the macromolecular marker horseradish peroxidase (HRP type VI, Sigma) were all added simultaneously on the mucosal side only. Their appearance on the serosal side was monitored by sampling $800 \mu \mathrm{l}$ aliquots of this compartment at $10,30,50,70$, and 90 minutes with buffer replacement. Radioactivity was measured on $500 \mu \mathrm{l}$ samples by liquid scintillation photometry (Kontron, SL4000) using double label correction. Mannitol and $\mathrm{Na}^{+}$fluxes were calculated according to their specific activity in the medium and expressed in $\mu \mathrm{mol} / \mathrm{h} . \mathrm{cm}^{2}$ and $\mu \mathrm{Eq} / \mathrm{h} . \mathrm{cm}^{2}$ respectively. Fluxes of intact horseradish peroxidase 
(ng/h. $\mathrm{cm}^{2}$ ) were assessed by measuring the enzymatic activity of peroxidase in $200 \mu \mathrm{l}$ serosal samples, as previously described. ${ }^{20}$ Fluxes are given at steady state, as the mean of the fluxes at 70 and 90 minutes.

ELECTRON MICROSCOPY

Studies were carried out on enterocytes of the middle villous region of the jejunum.

\section{Ultrathin sections}

Jejunal segments were fixed for one hour in $2.5 \%$ glutaraldehyde in $0.1 \mathrm{M}$ phosphate buffer, $\mathrm{pH} 7 \cdot 2$. Intestinal segments were postfixed in $1 \% \mathrm{OsO}_{4}$ in $0.1 \mathrm{M}$ phosphate buffer, dehydrated, and embedded in Araldite resin. Sections $120 \mathrm{~nm}$ thick were double stained with aqueous $0.5 \%$ uranyl acetate and lead citrate and observed under a Philips EM201 electron microscope operating at $80 \mathrm{kV}$.

\section{Freeze-fracture analysis of jejunal segments} Microvillus morphology and basolateral membrane plications were the variables used to identify mature and immature cells, for three reasons: the microvilli of undifferentiated crypt cells are shorter and less abundant than in differentiated absorptive cells, $P$ face particles are more numerous in the microvillus membranes of villus cells than in those of crypt cells, and plications of the basolateral membrane are present near the tight junctions, especially between cells near the villus tip. ${ }^{21}$ Here, glutaraldehyde fixed segments were cryoprotected with $25 \%$ glycerol in $0.1 \mathrm{M}$ phosphate buffer for 30 minutes, cut, and mounted on replica hats. Samples were frozen in pasty nitrogen, fractured in a freeze-fracture device (Cryofract, Reichert-Jung), shadowed with platinum, and coated with carbon under ultrahigh vacuum. Replicas were examined by electron microscopy after cleaning. To allow for variations within and between animals, replicas from two animals per group and two sites per animal were studied. In each group, strand numbers were quantified using 15 to 20 electron micrographs. On these micrographs straight lines were drawn perpendicular to the axis of the tight junction network every $0.2 \mu \mathrm{m}$, and the number of intersections with the tight junctions was counted and represented the number of strands. A mean strands number was then calculated for each electron micrograph. Overall, the tight junction length measured accounted for at least $30 \mu \mathrm{m}$ per group.

\section{STATISTICAL ANALYSIS}

Data were analysed with the SAS package (SAS Institute, Cary, NC, USA). Results are expressed as means (SD), with $\mathbf{n}$ as the number of animals or electron micrographs. Correlation and linear regression analysis were done to study the relation between numerical values. Means and ranges were compared by analysis of variance (ANOVA) using the general linear model procedure (least square means).

\section{Results}

NUTRITIONAL STATUS OF GUINEA PIGS

Throughout the three weeks of experimental feeding, control guinea pigs (NP group) gained weight as expected and exhibited normal plasma and intestinal protein concentrations (Table II). By contrast, the malnourished animals, in both the LP and LPZn groups, showed weight losses, which after 18 days resulted in a mean body weight that was below the initial level at weaning, and was half the mean body weight of the NP group. In the LP and LPZn groups, total plasma proteins were significantly reduced but intestinal mucosal proteins remained unchanged. As shown in the LPZn group, zinc treatment during malnutrition (LPZn) raised plasma and intestinal zinc concentrations. However, malnutrition alone did not modify zinc status, because in the LP group it remained close to normal.

INTESTINAL PERMEABILITY

Basal short circuit current was increased $(p=0.06)$ in the malnourished group (LP: $\left.50.49(16.59) \mu \mathrm{A} / \mathrm{cm}^{2}, \mathrm{n}=10\right)$ compared with the control group (NP: $39 \cdot 27(10 \cdot 11) \mu \mathrm{A} / \mathrm{cm}^{2}$, $\mathrm{n}=9$ ) but remained unchanged when malnourished animals were given additional zinc (LPZn: $\left.42.36(12 \cdot 18) \mu \mathrm{A} / \mathrm{cm}^{2}, \mathrm{n}=5\right)$. Ionic conductance, calculated as described in methods, increased significantly in intestinal segments from the LP group compared with segments from the NP and LPZn groups (Fig 1A). This increase in conductance was concomitant with an increase in mannitol and $\mathrm{Na}$ fluxes (Fig $1 \mathrm{~B}$ and $\mathrm{C}$ ). There was a linear relation between mannitol and $\mathrm{Na}$ fluxes (Fig 2); the slope of the relation was 58 , which was close to the theoretical value of 54 for the free diffusion of mannitol and $\mathrm{Na}^{22}$ Mannitol and $\mathrm{Na}$ fluxes were closely correlated $(r=0.981$, $\mathrm{p}<0.0001)$, and the intercept of this relation was $0.38 \mu \mathrm{Eq} / \mathrm{h} . \mathrm{cm}^{2}$. When malnourished guinea pigs were given the high zinc diet $(\mathrm{LPZn}$ group), all the permeability indices remained unchanged compared with control values $(p>0.5)$. Lastly, measurements of intact horseradish peroxidase fluxes disclosed no significant increase in the absorption of this macromolecular tracer (Fig 1D).

MORPHOLOGICAL FINDINGS

Initial examination of the apical region of the plasma membrane of enterocytes from NP, LP, and LPZn groups by thin section electron microscopy showed no morphological differences in this respect between the three dietary groups (not shown). Figure 3 shows freeze-fracture replicas of jejunal segments from the three groups. In these micrographs, a tight junction appeared as a network 
TABLE II Weight gain, plasma and mucosal proteins, and zinc concentrations in the three dietary groups of guinea pigs

\begin{tabular}{|c|c|c|c|c|c|c|}
\hline & $N P$ & $\begin{array}{l}\text { No of } \\
\text { guinea } \\
\text { pigs }\end{array}$ & $L P$ & $\begin{array}{l}\text { No of } \\
\text { guinea } \\
\text { pigs }\end{array}$ & $L P Z n$ & $\begin{array}{l}\text { No of } \\
\text { guinea } \\
\text { pigs }\end{array}$ \\
\hline $\begin{array}{l}\text { Weight gain (between } \\
\text { days } 0-18 \text { ) }\end{array}$ & $127(28)$ & 12 & $-39(15)^{\star}$ & 12 & $-31(12)^{\star}$ & 6 \\
\hline Plasma proteins $(\mathrm{g} / \mathrm{l})$ & $42 \cdot 6(6 \cdot 6)$ & 12 & $30.6(5 \cdot 7)^{\star}$ & 10 & $31 \cdot 8(5 \cdot 6)^{\star}$ & 6 \\
\hline $\begin{array}{l}\text { Mucosal proteins } \\
(\mathrm{g} / 100 \mathrm{~g})\end{array}$ & $13.9(1.4)$ & 10 & $13 \cdot 4(3 \cdot 3)$ & 11 & $14 \cdot 9(2 \cdot 2)$ & 6 \\
\hline Plasma zinc $(\mu \mathrm{mol} / \mathrm{l})$ & $22 \cdot 7(5 \cdot 6)$ & 12 & $21 \cdot 4(8 \cdot 9)$ & 10 & $48 \cdot 8(14 \cdot 6)^{\star} \dagger$ & 6 \\
\hline Mucosal zinc (nmol/g) & $215(68)$ & 12 & $298(81)$ & 10 & $930(426)^{\star} \dagger$ & 6 \\
\hline
\end{tabular}

Values are means (SD); NP=normal protein diet; $L P=$ low protein diet; $L P Z n=l o w$ protein diet with $1800 \mathrm{ppm}$ zinc.

${ }^{\star} \mathrm{p}<0.001 v \mathrm{NP} ;$ †p $<0.001 v$ LP.

composed of strands shown by fracture of the cytoplasmic leaflet of the plasma membrane ( $P$ face), and grooves produced by fracture of the exoplasmic leaflet ( $E$ face). The number of strands and grooves in the tight junction network was counted to assess the effect of malnutrition and zinc on structure of the tight junctions. Despite the absence of obvious differences between the appearance of the tight

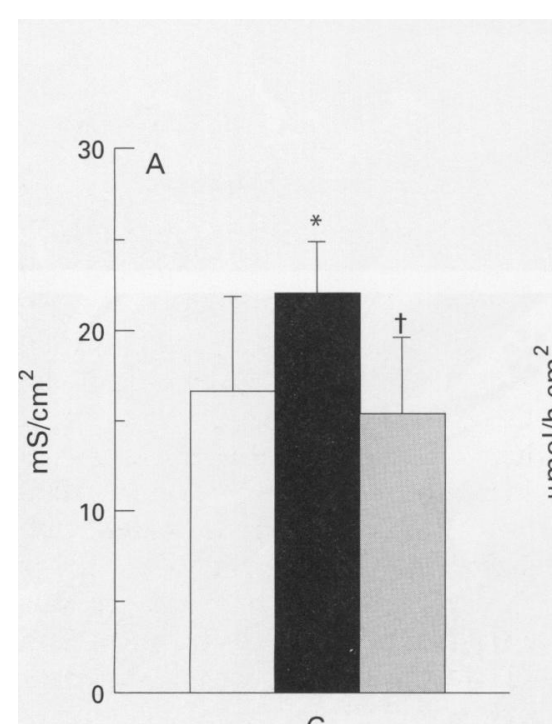

G
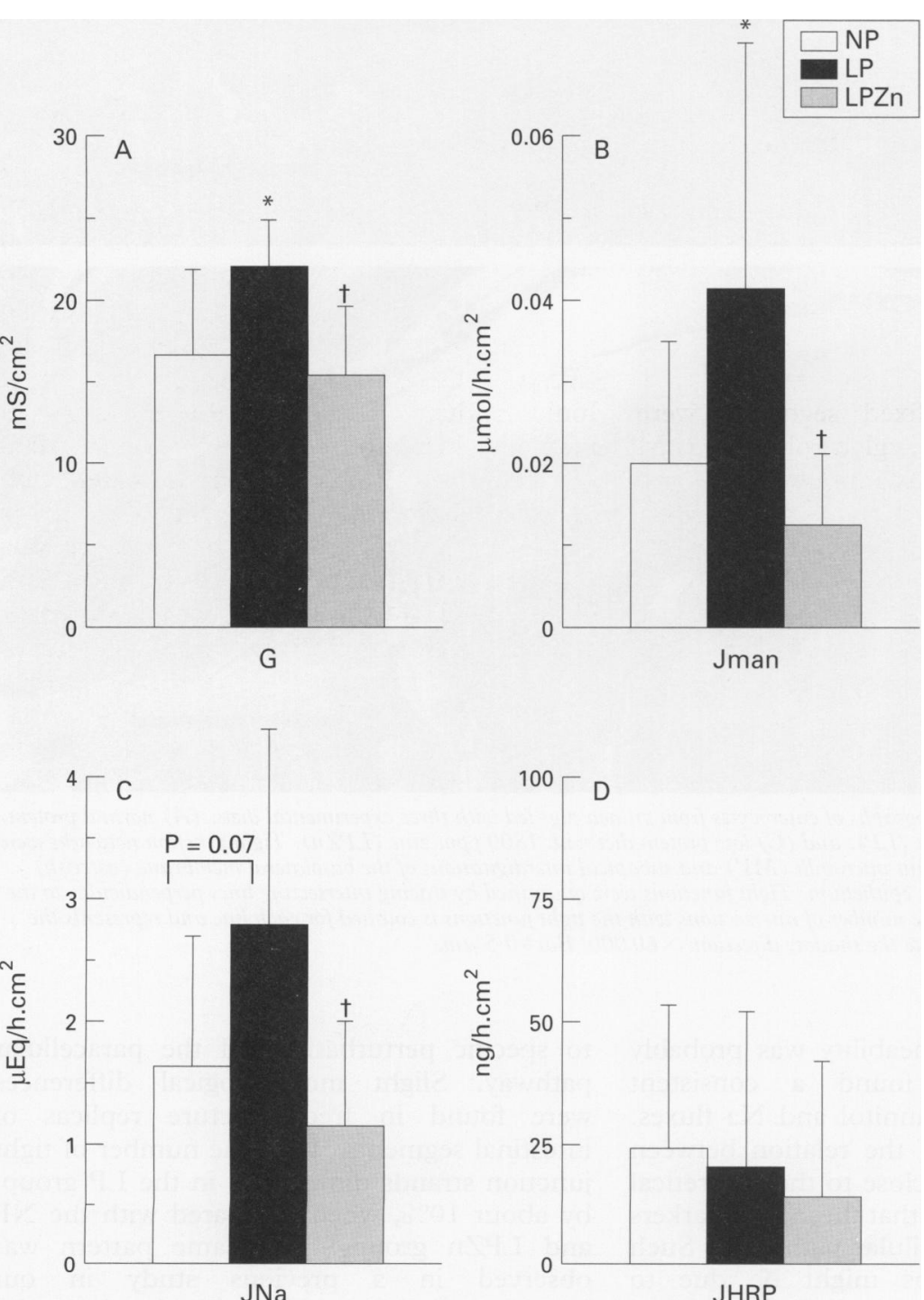

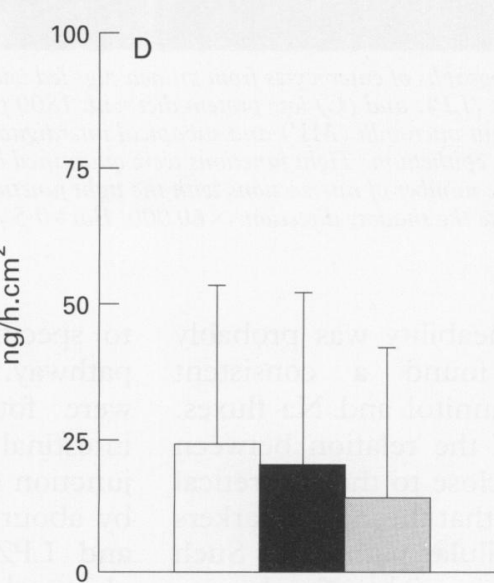

JHRP
Figure 1: Transepithelial ionic conductance and mucosal to serosal fluxes of mannitol, $\mathrm{Na}$, and horseradish peroxidase measured in Ussing chambers across jejunal segments from guinea pigs. Results are means (SD). The number of animals analysed was 9,10 , and 5 in the NP, LP, and LPZn groups respectively. ${ }^{\star} p<0.05 \mathrm{v} N P ; \dagger p<0.05 \mathrm{v} L P$. NP=normal protein diet; $L P=$ low protein diet; $L P Z n=$ low protein diet with 1800 ppm zinc. $(A)$ transepithelial ionic conductance $(G) ;(B)$ mannitol fluxes ( $(\mathcal{m}$ man); (C) sodium fluxes $(\mathfrak{F N a})$; (D) horseradish peroxidase fluxes (FHRP).

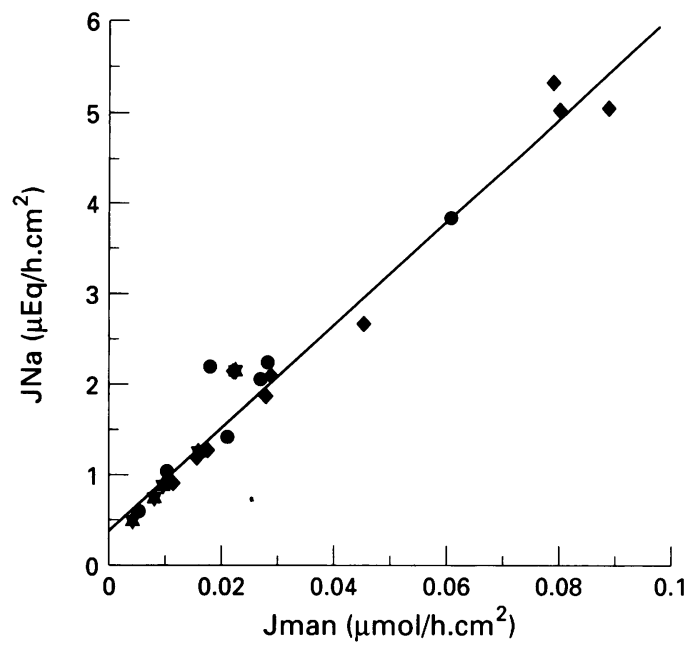

Figure 2: Relation between fluxes of mannitol (Fman) and $\mathrm{Na}(\mathcal{F N a})$ measured in Ussing chambers across jejunal segments of guinea pigs. Each point represents one animal. Circle $=$ normal protein diet $(N P)$; square=low protein diet (LP); star=low protein diet with 1800 ppm zinc (LPZn).

The correlation between $\mathrm{Na}$ and mannitol fluxes is significant $(\mathrm{r}=0.981, p<0.0001)$ and the slope of this linear relation is 58. This is close to the theoretical value of 54 for the free diffusion of mannitol and $\mathrm{Na}$, indicating that both markers use the same paracellular pathway.

junctional network in the three groups studied (Fig 3), jejunal epithelia from animals in the LP group, but not from those in the LPZn group, exhibited $10 \%$ less tight junctional strands than epithelia from animals in the NP group (Table III). We concede that application of ordinary hypothesis testing to these results would be flawed on account of nonindependence of different sites in the same animals; the design of our study followed others $^{1123}$ that also failed to allow for this. Another study in our laboratory, ${ }^{24}$ using malnourished animals fed $4 \%$ milk proteins (instead of $4 \%$ soya proteins in this study) also showed that the number of strands decreased by $15 \%$ in malnourished animals (strands number $=4 \cdot 50$ ) compared with control animals (strands number $=5 \cdot 28$ ).

\section{Discussion}

These results confirm that intestinal ionic conductance ${ }^{6-25}$ and unidirectional fluxes of small solutes ${ }^{7}$ increase during experimental malnutrition, indicating that paracellular permeability is altered. They further suggest that this functional abnormality is associated with a reduction in the number of strands constituting the tight junctions. Our results also show that treatment with a pharmacological dose of zinc prevents intestinal changes found in malnourished guinea pigs.

In this study, malnutrition caused functional changes in the intestine. Firstly, the total electrogenic transport of ions, short circuit current, increased, thereby confirming previous findings ${ }^{6} 8$ and suggesting that malnutrition induces a hypersecretory state in the intestine. This increase in short circuit current is not due to increased $\mathrm{Na}^{+}$-glucose cotransport, ${ }^{26}$ because no glucose was added in our experiments. Secondly, ionic conductance as well as mannitol and $\mathrm{Na}$ permeabilities also 

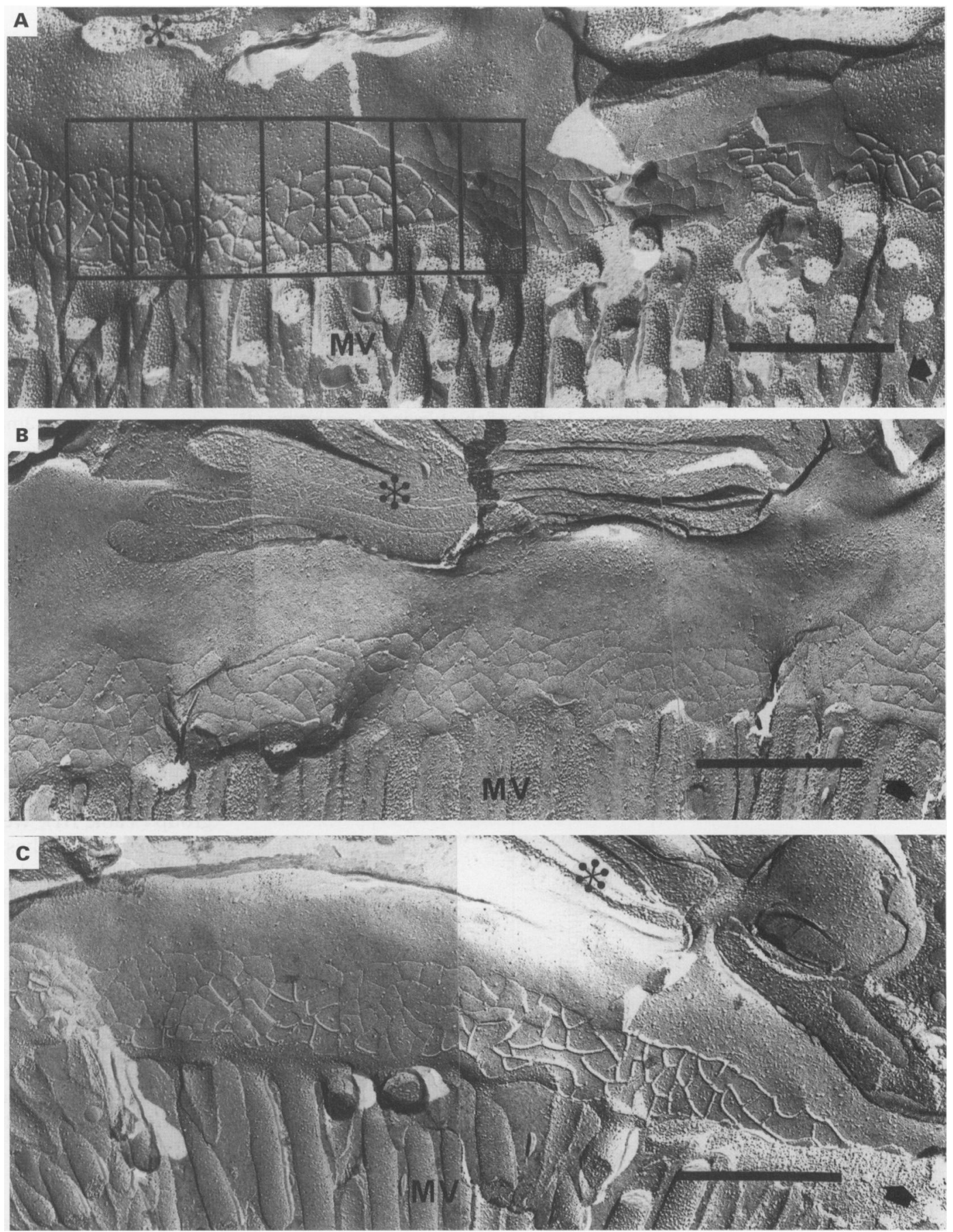

Figure 3: Freeze-fracture micrographs of enterocytes from guinea pigs fed with three experimental diets. $(A)$ normal protein diet (NP); (B) low protein diet (LP); and (C) low protein diet with 1800 ppm zinc (LPZn). Tight junction networks were similar in appearance. Abundant microvilli (MV) and subapical interdigitations of the basolateral membrane (asterisk) characterised the jejunal villous epithelium. Tight junctions were quantified by tracing intersecting lines perpendicular to the axis every $0 \cdot 2 \mu \mathrm{m}$ (see $A$ ). The number of intersections with the tight junctions is counted for each line and represents the strands number. Arrows indicate the shadow direction. $\times 60000$. Bar $=0.5 \mu \mathrm{m}$.

rose. This rise in permeability was probably paracellular, as we found a consistent correlation between mannitol and $\mathrm{Na}$ fluxes. Moreover, the slope of the relation between them was 58 - that is, close to the theoretical value of 54 - suggesting that these two markers shared the same paracellular pathway. ${ }^{22}$ Such functional perturbations might be due to morphological alteration of the intestine, because malnutrition is generally reported to alter intestinal histology at both the light and electron microscopy levels. ${ }^{27}{ }^{28}$ In our study, the absence of epithelial necrosis indicated that the increase in permeability was probably due to specific perturbations of the paracellular pathway. Slight morphological differences were found in freeze-fracture replicas of intestinal segments. Thus the number of tight junction strands diminished in the LP group, by about $10 \%$, when compared with the NP and LPZn groups. The same pattern was observed in a previous study in our laboratory, ${ }^{24}$ using malnourished guinea pigs fed a low protein diet ( $4 \%$ milk proteins instead of $4 \%$ soya proteins in this study), in which the strands number decreased by $15 \%$ in malnourished animals compared with control animals. It has previously been suggested that 
TABLE III Quantification of tight junctions in freezefracture replicas of jejunum from the three dietary groups of guinea pigs

\begin{tabular}{ll}
\hline & Strands number \\
\hline NP $(n=20)$ & $5 \cdot 21(0 \cdot 50)$ \\
LP $(n=15)$ & $4 \cdot 79(0 \cdot 41)$ \\
LPZn $(n=15)$ & $5 \cdot 07(0 \cdot 62)$
\end{tabular}

Values are means (SD); $\mathrm{NP}=$ normal protein diet; $\mathrm{LP}=$ low protein diet; $\mathrm{LPZn}=$ low protein diet with $1800 \mathrm{ppm}$ zinc. $\mathrm{n}$ is the number of electron micrographs analysed, taken from two sites per animal and from two animals per group.

due to the nature of the transepithelial resistance, relatively minor alterations in junctional permeability produce substantial alterations in electrical resistance, ${ }^{23} 29$ and that the presence of a small subpopulation of epithelial cells with permeable junctions may quickly decrease transepithelial resistance before obvious permeability changes are detected. ${ }^{22}$

In our model, only the permeability to small molecules was modified, without any changes in macromolecular horseradish peroxidase transport. It has generally been reported that under conditions of protein malnutrition, the intestine becomes more permeable to macromolecules. However, in most animal studies in which macromolecular absorption increased during malnutrition, animals were fed a diet containing milk proteins. ${ }^{4-6}$ In this connection, we showed in a previous investigation that in guinea pigs, the increase in macromolecular (horseradish peroxidase) permeability is linked to the presence of cows' milk proteins in the diet and to subsequent milk sensitisation. ${ }^{30}$ This is consistent with the absence of modification in protein permeability reported in mice given a low protein milk free soya based formula. ${ }^{31}$

Although the present low protein diet did not in itself induce hypozincaemia or intestinal zinc depletion, feeding malnourished guinea pigs with a large amount of dietary zinc prevented the increases in short circuit current, ionic conductance, and $\mathrm{Na}$ and mannitol fluxes found in the LP group without additional zinc (Fig 1). Zinc has been found to be beneficial in clinical trials of zinc supplementation in developing countries where the prevalence of zinc deficiency is high. ${ }^{32}$ In many of these trials, supplementation consisted of physiological doses of zinc, given during the nutritional rehabilitation phase. Under such clinical conditions, the efficacy of zinc may mostly be due to the covering of the high zinc requirement known to be associated with catch up growth. ${ }^{33}$ By contrast, in the present experiments, zinc was given at high doses throughout the period of malnutrition. Under these conditions, its efficacy in improving intestinal permeability suggests a specific role in maintaining intestinal structure and function. Ultrastructural lesions of the intestinal mucosa, as well as changes in the net transport of water, electrolytes, and glucose have been reported in zinc deficient rats. ${ }^{34} 35$ Zinc is an essential micronutrient present in biomembranes. It stabilises membrane structure and is involved in membrane function by interacting, especially at $\mathrm{SH}$ group level, with membrane enzymes, transporters, receptors, and channels. ${ }^{36}$ Zinc also interacts with intestinal phospholipids, protecting them from degradation. ${ }^{37}$ This might explain why zinc prevented the activation of short circuit current in our malnourished guinea pigs, as experimental malnutrition was shown to be associated with an alteration in lipids in the microvillus membrane, ${ }^{26}$ which may be involved in intestinal dysfunction, especially in alterations affecting active electrolyte transport. The beneficial role of zinc in function of the epithelial barrier has been shown both in vitro ${ }^{15}{ }^{16}$ and in vivo. ${ }^{138}$ In vitro studies showed that zinc deficiency induced partial disruption of the endothelial barrier ${ }^{15}$ and that adding zinc to the normal culture medium totally prevented the disruption of this barrier induced by $T N F \alpha .{ }^{16}$ In vivo studies showed that the increased intestinal permeability in children with diarrhoea was significantly reduced by zinc supplementation. ${ }^{138}$ Previous findings regarding the effects of severe zinc deficiency on intestinal permeability in rats have shown that the integrity of junctional complexes, as assessed by lanthanum hydroxide diffusion, did not alter. ${ }^{39}$ However, this study indicates that a high zinc diet maintains a normal intestinal permeability in malnourished guinea pigs. Our morphological findings further suggest that zinc may prevent the loss of barrier function induced by malnutrition at the tight junctional level. Such hypothetical interaction between zinc and tight junctions may be related to the regulation of zinc sensitive genes in the intestine ${ }^{40}$ or to the binding of zinc to cytoskeletal proteins, ${ }^{41}{ }^{42}$ the role of which in regulating intestinal tight junctions is well established. ${ }^{10} 22$

In conclusion, our findings show that experimental malnutrition increases intestinal paracellular permeability to small molecules and that this increase is fully prevented by pharmacological doses of zinc. They further suggest that such intestinal dysfunction might take place in the tight junctions, the stabilisation of which may be improved by zinc. The exact mechanism involved in the effects of zinc remains to be determined, as well as its clinical relevance to human malnutrition.

We thank the Centre Inter-universitaire de Microscopie Electronique (CIME-Jussieu) for carrying out the electron microscopy studies. We are also grateful to D Raison for her excellent technical assistance and to $M$ Dreyfus for editorial assistance. PR was supported by a CONICIT-BID Venezuelan scholarship. This work was supported in part by grants from the VOLVIC Research Center on Trace Elements.

1 Roy SK, Behrens RH, Haiders R, Akramuzzaman SM, Mahalanabis D, Wahed MA, et al. Impact of zinc supplementation on intestinal permeability in Bangladeshi children with acute diarrhoea and persistent diarrhoea syndrome. $f$ Pediatr Gastroenterol Nutr $1992 ; 15$ : 289-96.

2 Sazawal S, Black RE, Bhan MK, Bhandari N, Sinha A Jalla $S$. Zinc supplementation in young children with acute diarrhoea in India. $N$ Engl $f$ Med 1995; 333: acute diart

3 Heyman M, Boudraa G, Sarrut S, Giraud M, Evans L, Touhami $M$, et al. Macromolecular transport in jejunal mucosa of children with severe malnutrition: a quantitative study. F Pediatr Gastroenterol Nutr 1984; 3: 357-363. 
4 Rothman D, Lathman MC, Walker WA. Transport of macromolecules in malnourished animals: II intravenous clearance after antigen absorption. Nutr Res 1982; 2: 475-80.

5 Worthington BS, Syrotuck J. Intestinal permeability to large particles in normal and protein-deficient adult rats. $₹$ Nutr particles in normal

6 Darmon N, Pélissier MA, Heyman M, Albrecht R, Desjeux JF. Oxidative stress may contribute to the intestinal dysfunction of weanling rats fed a low protein diet. $\mathcal{F} \mathrm{Nutr}$ 1993; 123: 1068-75.

7 Carey HV, Hayden UL, Tucker KE. Fasting alters basal and stimulated ion transport in piglet jejunum. Am $\mathcal{F}$ Physiol 1994; 267: R156-63.

8 Butzner JD, Gall DG. Impact of protein-calorie malnutrition on the developing intestine. A model of young rabbits. Biol Neonate $1988 ; 54: 151-9$.

9 Powell DW. Barrier function of epithelia. Am $\mathcal{F}$ Physiol 1981; 241: G275-88.

10 Madara JL, Stafford J, Barenberg D, Carlston S. Functional coupling of tight junctions and microfilaments in T84 coupling of tight junctions and microfilaments

11 Madara JL, Pappenheimer JR. Structural basis for physiological regulation of paracellular pathways in intestinal epithelia.

12 Madara JL, Stafford J. Interferon- $\gamma$ directly affects barrier function of cultured intestinal epithelial monolayers. $\mathcal{F}$ Clin Invest 1989; 83: 724-7.

13 Rodriguez $\mathrm{P}$, Heyman $\mathrm{M}$, Candalh $\mathrm{C}$, Blaton $\mathrm{MA}$, Bouchard C. Tumor necrosis factor alpha induces morphological and functional alterations of intestinal HT29 cl19A cell monolayers. Cytokine 1995; 7: 441-8.

14 Nash S, Stafford J, Madara JL. The selective and superoxide independent disruption of intestinal epithelial tight junctions during leukocyte transmigration. Lab Invest junctions during

15 Hennig B, Wang Y, Ramasamy S, McClain CJ. Zinc deficiency alters barrier function of cultured porcine endothelial cells. $\mathcal{F}$ Nutr 1992; 122: 1242-7.

16 Hennig B, Wang Y, Ramasamy S, McClain CJ. Zinc protects against tumor necrosis factor-a induced disruption of porcine endothelial cell monolayer integrity. f Nutr 1993; 123: 1003-9.

17 Navia JM, Hunt CE. Nutrition, nutritional diseases, and nutrition research applications. In: Wagner JE, Manning PJ, eds. The biology of the guinea-pig. New York: Academic Press, 1976: 235-67.

18 Walsh CT, Sandstead HH, Prasad AS, Newberne PM, Fraker PJ. Zinc: health effects and research priorities for the 1990s. Environ Health Perspect 1994; 102 (suppl 2): 5-46.

19 McCance RA, Widdowson EM. Protein-deficiencies and calorie deficiencies. Lancet 1966; ii: 158-9.

20 Maehly AC, Chance B. The assay of catalases and peroxidases. In: Glick D, ed. Methods of biochemical analysis, vol 1. New York: Wiley, 1954: 357-98.

21 Madara JL, Trier JS. The functional morphology of the mucosa of the small intestine. In: Johnson LR, ed. Physiology of the gastrointestinal tract. Chapter 45. New York: Raven Press, 1994: 1577-622.

22 Madara JL, Barenberg D, Carlson S. Effects of cytochalasin $D$ on occluding junctions of intestinal absorptive cells: further evidence that the cytoskeleton may influence paracellular permeability and junctional infuence paracellular permeability and junction

23 Marcial MA, Carlson S, Madara JL. Partitioning of paracellular conductance along the ileal crypt-villus axis: a hypothesis based on structural analysis with detailed consideration of tight junction structure-function relationships. $\mathcal{F}$ Membrane Biol 1984; 80: 59-70.

24 Rodriguez P, Darmon N, Heyman M, Bouchaud C. Effect of protein malnutrition on guinea-pig intestinal tightof protein malnutrition on guinea-pig intestinal tight-
junctions. Structure/activity relationship. Electron junctions. Structure/activity relationship. Electron Microscopy, ed. Les éditions de Phy
Biological Sciences 1994; 3: 193-4.

25 Young A, Levin RJ. Diarrhoea of famine and malnutrition investigations using a rat model. 1-Jejunal hypersecretion induced by starvation. Gut 1990; 31: 43-53.

26 Butzner JD, Brockway PD, Meddings JB. Effects of malnutrition on microvillus membrane glucose transport and physical properties. Am $\mathcal{f}$ Physiol 1990; 259: G940-6.

27 Shiner M. Immune mechanisms in the small bowel mucosa of children with malnutrition: ultrastructure and correlation with function. Front Gastrointest Res 1986; 13:
172-86.

Guiraldes E, Hamilton J R. Effect of chronic malnutrition on intestinal structure, epithelial renewal and enzymes in on intestinal structure, epithelial renewal a
suckling rats. Pediatr Res 1981; 15: 930-4.

29 Gonzalez-Mariscal L Contreras RG, Bolivar JJ, Ponce A, Chavez de Ramirez B, Cereijido M. Role of calcium in Chavez de Ramirez $\mathrm{B}$, Cereijido $\mathrm{M}$. Role of calcium in tight junction formation betwe

30 Darmon N, Heyman M, Candalh C, Blaton M, Desjeux JF. Anaphylactic intestinal response to milk proteins during malnutrition in guinea-pigs. Am $\mathcal{F}$ Physiol 1996; 270: 442-8.

31 Lamont AG, Gordon M, Ferguson A. Oral tolerance in protein-deprived mice: II. Evidence of normal 'gut processing' of ovalbumin, but suppressor cell deficiency, in deprived mice. Immunology 1987; 61: 339-43.

32 Gibson RS. Zinc nutrition in developing countries. Nutr Res Rev 1994; 7: 151-73.

33 Golden MHN, Golden BE. Effect of zinc supplementation on the dietary intake, rate of weight gain, and energy cost on the dietary intake, rate of weight gain, and energy cost of tissue deposition in children recovering from

34 Elmes ME, Jones JG. Ultrastructural changes in the small intestine of zinc deficient rats. $\mathcal{F}$ Pathol 1980; 130: $37-43$

35 Ghishan FK. Transport of electrolytes, water, and glucose in zinc deficiency. $\mathcal{F}$ Pediatr Gastroenterol Nutr 1984; 3: 608-12.

36 Bettger WJ, O'Dell BL. Physiological roles of zinc in the plasma membrane of mammalian cells. $\mathcal{f}$ Nutr Biochem 1993; 4: 194-207.

37 Tacnet F, Ripoche P, Roux M, Neumann JM. ${ }^{31}$ P-NMR study of pig intestinal brush-border membrane structure: effect of zinc and cadmium ions. Eur Biophys $\mathcal{f}$ 1991; 19: 317-22.

38 Alam AN, Sarker SA, Wahed MA, Khatun M, Rahaman MM. Enteric protein loss and intestinal permeability
changes in children during acute shigellosis and after changes in children during acute shigellosis and after recovery:

39 Moran JR, Lewis JC. The effects of severe zinc deficiency on intestinal permeability: an ultrastructural study. Pediatr Res 1985; 19: 968-73.

40 Shay NF, Cousins RJ. Cloning of rat intestinal mRNAs affected by zinc deficiency. $\mathcal{F}$ Nutr 1993; 123: 35-41.

41 Strzelecka-Golaszewska H, Prochniewicz E, Drabikowski W. Interaction of actin with divalent cations: 1 the effect of various cations on the physical state of actin. Eur $f$ Biochem 1978; 88: 219-27.

42 Serrano L, Dominguez JE, Avila J. Identification of zincbinding sites of proteins: zinc binds to the amino-terminal region of tubulin. Anal Biochem 1988; 172: 210-8. 